\title{
Cranial Cruciate Ligament Rupture in a Cat
}

\author{
Yoshiharu OKAMOTO, Saburo MINAMI, Kazuto YAMASHITA, \\ and Akira MATUHASHI
}

前十字鞀帯断裂を呈した猫の一例

岡本 芳晴, 南 三郎, IL下 和人, 松橋 哠

\section{Introduction}

Cranial cruciate ligament $(\mathrm{CCL})$ injury is a common disease in the dog and many surgical techniques have developed ${ }^{4,6}$. However, this disease in the cat appears to be much less, and a few cases treated surgically have been reported $1,2,3,8,9)$. In the feline CCL rupture, most of the surgical reports employed Paatsama's classic technique $^{3,8)}$ or its modified methods ${ }^{2,11)}$ without no post-operative troubles. On the other hand, Butler $(1964)^{2)}$ pointed out the several disadvantages in the procedure as Paatsama originally described using fascia in dogs, such as the questionable strength of the fascia transplanted, neccesity of splinting and so on. In the cat, there have been no literature about the fate of the fascia transplant and the stifle joint function.

We treated a cat with CCL rupture using a fascia, however, the result was unsatisfactory. In this paper, we describe the precise management of this case, and discuss speculative causes of the breaking fascia.

\section{Clinical case and radiographic findings}

A two-year-old female Japanese short hair domestic cat weighing $3.6 \mathrm{~kg}$ was referred to the University Veterinary Hospital for an abnormal gait and the loss of vigor.

鳥取大学農学部（鳥取市湖山町南 4-101）

Department of Veterinary Surgery, Faculty of

A.griculture, Tottori University, Koyama-cho,

Tottori 680, Japan.
Physical examination revealed redness of the skin in the region from the stifle joint to the toe of the left hindleg, and an anterior drawer sign of the tibia in the same leg was observed under the general anesthesia. Lateral radiography demonstrated the cranial displacement of the tibia against the distal femur of the left hindleg (Fig. 1). Left elbow joint was also completely luxated.

\section{Surgical correction}

After atropine sulfate $(0.05 \mathrm{mg} / \mathrm{kg})$ and diazepam $(2.0 \mathrm{mg} / \mathrm{kg})$ were administered subcutaneously, anesthesia was induced with ketamine-HCL $(20 \mathrm{mg} / \mathrm{kg})$ injected intramuscularly and maintained with a mixture of oxygen ( $1 \mathrm{~L} / \mathrm{min}$.), nitrous oxide $(2 \mathrm{~L} / \mathrm{min}$.) and halothane $(1-3 \%)$.

Lateral approach to the stifle was performed for the cruciate ligaments exposure, and the extended CCL, approximately $1 \mathrm{~cm}$ in length, was clearly observed. Partial rupture of the caudal cruciate ligament was also detected. No other soft tissue injuries around the stifle joint and no meniscal injuries were observed. After removal of the extended cranial cruciate ligament, the intracapsular reconstruction was performed by Paatsam's classic procedure ${ }^{6}$. In addition, extracapsular reconstruction was also carried out by lateral retinacular imbrication technique ${ }^{4}$ with No. 5 braided silk (U.S.P.). The incision was closed in a routine manner. The cat released to the owner on the 3rd day after the surgery. Owner was requested to confine the cats in a cage to restrict the movement. 


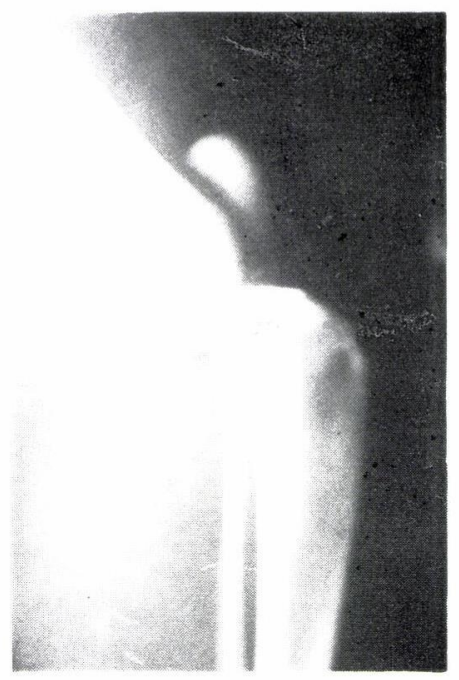

Fig. 1. A left lateral radiograph of the left stifle joint taken prior to surgery, showing excessive anterior movement of the tibia.

On the 8th day of post-operation, the owner complained the lameness of the left foreleg and the left hindleg. The owner also told us that the cage rest was performed for only a day because of the rampage and crying of the cat all day and of escaping from the cage. On the physical examination, there was mild swelling in the left elbow joint without pain and fever. Lateral radiography revealed the elbow lateral luxation and recurrence of the cranial displacement of the tibia.

Lateral approach of the left stifle joint was carried out. Completely breaking of both the transplant and No. 5 silk suture as a lateral retinaculum were detected. The similar intracapsular reconstruction was performed with No. 4 (U.S.P.) nylon suture in place of the fascial transplant. At the same time, the elbow luxation was reduced surgically. Utilizing the casting tape, extra-fixations of both the affected legs were performed (Fig. 2).

On 14th day after the second surgery, the casts and skin sutures were removed and then passive mobilization of both legs was carried out for 2 weeks. The elbow and stifle joints were stable at the extended or flexed position and their functions were gradually recovered. A month after the second surgery, the animal showed almost complete weight-bearing on the both legs and

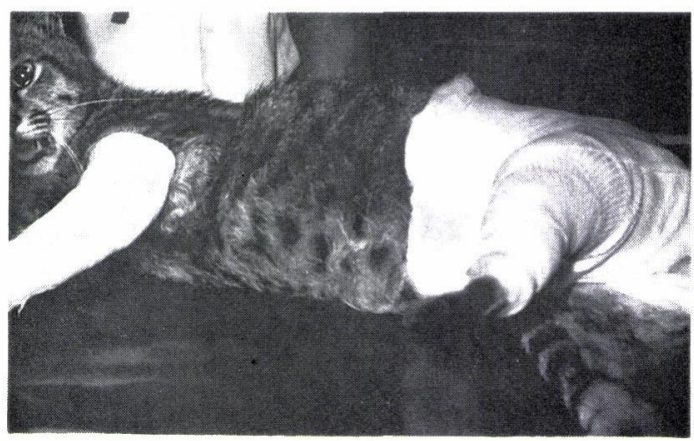

Fig. 2. After the second surgery, the affected limbs were fixed using casting tape.

normal gait.

\section{Histological findings of the removed cruciate ligament}

The excised CCL was examined histologically and its findings were shown in Fig. 3. Moderate rupture of the collagen fibers with a few inflammatory cells were observed. No degeneration of CCL was observed bistologically.

\section{Discussion}

Treatments of feline CCL rupture were divided into 2 groups, conservative and surgical treatments ${ }^{6}$. Conservative therapy may be considered when severe degenerative joint disease is already present at the time of initial diagnosis. In dogs, it was suggested that the majority of small dogs would recover after 2 months of enforced rest, whereas large dogs apparently did not show the similar recovery by the rest ${ }^{6)}$. On the other hand,

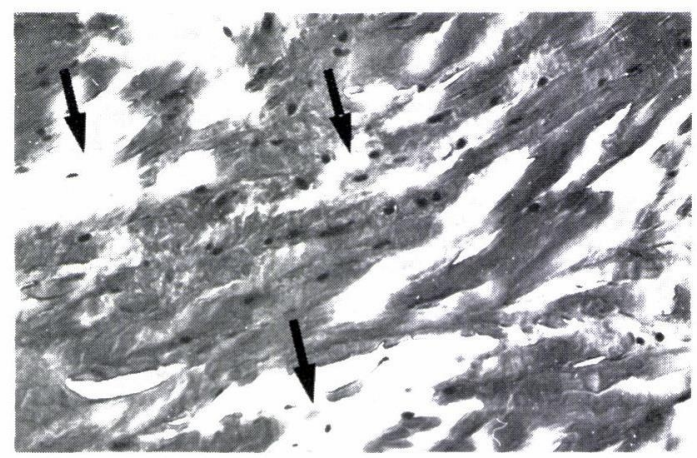

Fig. 3. A histological finding of the excised anterior cruciate ligament, showing moderate rupture of the collagen fibers (arrows). H.E. $(\times 200)$ 
Scavelli and Schreder (1987) $)^{10}$ reported nonsurgical managements in cats and that all 18 cats recovered normal gait and limb function after 4.8 weeks (range 1 to 16 weeks) confinement and strict rest. This may suggest that most cases of small dogs and cats will recover normal gait without surgical reconstruction of CCL rupture.

However, many surgical techniques have been described for the replacement of the CCL in the $\operatorname{dog}^{6,8)}$. In cats, the similar techniques have been accepted without detail examinations ${ }^{1}$. In the present case, we used the Paatsam's and De Angelis' lateral suture techniques because these techniques were popular and simple compared with other techniques. However, on the 8th day of post-operation, the fascial strip and No. 5 silk suture were simultaneously ruptured. One of the causes may be the excessive load to the affected leg during the rampage in the cage. In general, the animal should be kept in a cage for a few weeks after the operation ${ }^{6)}$. Another possible cause may be that the fascial strip of the cat is too weak to stabilize the stifle joint in comparison with dog's one. There are no reports concerning the fate of fascia transplant in the feline stifle and whether the broken fascia transplant may impair the function of stifle or not. In feline CCL rupture, most of cases receiving surgica] treatment were successful, however, it does not mean that all transplants did not break, because satisfactory recovery could be expected through only a strict rest for approximately one month.

In the second operation, we performed the similar intracapsular reconstruction with No. 4 nylon in place of fascial strip and extrafixation. Many investigators have reported the use of non-absorbable materials such as nylon or teflon in place of fascial strip ${ }^{8}$. In the present case, it is suggested that intracapsular reconstruction with nylon is possible if enough extrafixation is performed in the cats. Further examination is necessary to establish the better methods for the stifle joint reconstruction, including selection of the materials.

\section{References}

1) Alexander, J.W., Shumway, J.D., Lau, R.E. and Westfall, G.J. (1977): Anterior cruciate ligament rupture. Feline Pract. 7: 38-39.

2) Butler, H.C. (1964): Teflon as a prosthetic ligament in repair of ruptured anterior cruciate ligaments. Am. J. Vet. Res. 25: 55-59.

3) Cucuel, J.P.E. and Frye, F.L. (1970): Anterior cruciate ligament repair in a cat. VM/ SAC. $65: 38$.

4) De Angelis, M. and Lau, R.E. (1970): A lateral retinacular imbrication technique for the surgical correction of anterior cruciate ligament rupture in the dog. J. Am. Vet. Med. Assoc. 157: 79-84.

5) Gupta, B.N. and Brinker, W.O. (1969): Anterior ligament prosthesis in the dog, J. Am. Vet. Med. Assoc. 154: 1057.

6) Hulse, D.A. and Shires, P.K. (1985): The Stifle Joint. In: Textbook of Small Animal Surgery (Slatter, D.H. ed.), pp. 2193-2235. W.B. Saunders, Philadelphia.

7) Knecht, C.D. (1976): Evolution of surgical techniques for cruciate ligament rupture in animals. J. Am. Anim. Hosp. Assoc. 12: 717-726.

8) MacManus, J.L. and Nimmons, G.B. (1967): Ruptured anterior cruciate ligament in a cat. Canad. Vet. J. 7: 264.

9) Pearson, P.T., McCurnin, D.M., Carter, J.D. and Hoskins, J.D. (1971): Lembert suture technique to surgically correct ruptured cruciate ligaments. J. Am. Anim. Hosp. Assoc. 7: 1-13.

10) Scavelli, T.P. and Schreder, S.C. (1987): Nonsurgical management of the cranial cruciate ligament in 18 cats. J. Am. Anim. Hosp. Assoc. 23: 337-340.

11) Strande, A. (1964): A study of the replacement of the anterior criucate ligament in the dog by tendon of flexor digitalis longus. Nord. Vet. Med. 16: 820-827.

\section{要 約}

左後肢の跛行を呈する 2 歳の日本猫に見られた 前十字䩒帯断裂に観血的な治療を実施した。左後 肢膝関節には典型的な脛骨の前方滑り症を確認し た。膝関節の再建には Paatsam 原法および 5 号 綟糸 (U.S.P.) を用いた De Angelis 法を併用し たが術後 8 日目に移植筋膜および絹糸の断裂によ って前方滑り症が再発し, 筋膜の代わに 4 号ナイ ロン糸を用い Paatsam の方法に準じ再手術を実 施した。運動制御の目的で患肢に Casting tape 
による外部固定を実施した。術後 2 週目に外部固 定を除去し，患肢にはリハビリテーションを施し たところ，漸次患肢の機能回復を認めた。摘出し た前十字靶帯の組織学的観察で膠原線維の変性像 は見られず，本症の原因は外傷性と考号れた。
また，猫では外部固定は不必要とされているが， 本症例のごとく特に性格のきつい日本猫では移植 筋膜の断裂が生ずることが明らかとなり，猫にお ける本症の外科的整復の一失敗例として貴重と考 え報告した。 